\title{
The challenge of information technology transfer and diffusion $^{1}$
}

\author{
Priscilla Fowler \\ Software Engineering Institute, Carnegie Mellon University, \\ Pittsburgh, PA, 15213 US, Tel. (412) 268-7748, Fax (412) 268-5758, \\ pjf@sei.cmu.edu
}

An important area within information technology (IT)-technology transfer and diffusionhas emerged. It includes diffusion (Rogers 1983, Redwine 1984, McKenney 1995) and adoption and implementation in organizations (Kwon and Zmud 1987, Leonard-Barton 1987, Fichman 1992) of software and IT innovations. This new area has attracted the interest of both the research and the practice communities. For example, four IEEE Computer Society workshops on software engineering technology transfer have been held (Morton 1983, Przybylinski and Fowler $1987^{2}$ ). A growing community of software process improvement network (SPIN) groups has emerged (Peterson $1995^{3}$ ). Major consortia and government institutions such as the Software Engineering Institute and the ESPRIT program have been established to address software and IT issues, emphasizing technology transfer and diffusion. And a growing body of research and practice on the introduction of software and IT in organizations is being published (for example, Nord and Tucker 1987, Eason 1988, Pressman 1988, Bouldin 1989, Fowler 1990, Strauss and Ebenau 1994).

There is much to learn from research on and experience with the transfer of technologies in general (Downs and Mohr 1976, Rogers 1983, Von Hippel 1988, Tornatzky and Fleischer 1990, Roberts 1991). Nonetheless, the process-intensive nature of software and IT requires that we understand what is unique about transfer in these cases. Which models and approaches to technology transfer and diffusion are specific to IT, including information systems and methods for developing and evolving them? What does the manager, engineer, or information systems analyst need to know about technology transfer, and what is best practice? What can the research community contribute? To answer these questions, we need to understand the nature of IT transfer and diffusion.

Reflecting the increased interest in IT transfer and diffusion in a number of domains, definitions and terms vary. IT can be sold, licensed, spun out, disseminated, infused, transplanted, modified, appropriated, unbundled, absorbed, adopted, implemented, and inserted (Zmud and Apple 1992, Lien 1992). Context for the application of new technology varies widely (Fowler and Levine 1992), and can include: work groups of various sizes within an organization, entire organizations (small or large), communities, regions, countries, or the international market. Technology maturity can vary as well: transfer and diffusion out of R\&D is quite different than

1. This work is sponsored by the United States Department of Defense.

2. These are the first and third conferences; the second and fourth had no proceedings published.

3. In a July 1995 presentation at the Software Engineering Institute, Bill Peterson, director of the SEI's Process Program, reported that in 1989, 46 people attended the first Software Engineering Process Group (SEPG) National Meeting; in 1995, 1,248 attended the (renamed)

SEPG Conference. He also reported that there are now 54 SPIN groups, each representing a regional or national group of SEPGs. 
that required for new product development (Moore 1991). Internal capability to "pull" technology into a context also varies; for example, small firms often do not have the "slack" resources (Rogers 1983) to track, evaluate, and integrate new products and technologies. But while there is a groundswell of interest in this emerging area, understanding of it is fragmented (Kwon and Zmud 1987); work is hampered by lack of a common perspective. IFIP Technical Committee (TC) 8's WG8.6 was established in March of 1994 to provide a forum and a focus for, and to expedite progress in, both research and practice in IT transfer and diffusion.

Based on the research and practice that has been documented, and the findings of this recent conference, there is no question that the IT transfer and diffusion is a crucial area to address. Many key technologies-avionics and high-speed ground transport, medical equipment and telecommunications networks, automobiles and entertainment systems-are now informationor software-intensive. IT and software are changing the shape of our enterprises and are demanding the evolution of new organizational paradigms. It is in this exciting context that the first official working conference of IFIP WG8.6 was convened. The program reflected a lively mix of case studies (on a wide range of technologies and adoption and implementation situations), practical methods and tools, and models. Three keynote speakers, John Leslie King, David Talbot, and Kalle Lyytinen, presented theoretical and practical issues for us to address. Participants, from a wide range of backgrounds, contributed questions, insights, and dialogue. The program co-chairs and the organizing committee prepared an excellent environment that facilitated constant and enjoyable interchange. It is clear that a community with energy and dedication has emerged, and that, with this conference, WG8.6 is off to an excellent beginning!

\section{Priscilla Fowler}

Chair, IFIP Working Group 8.6 on Diffusion, Transfer and Implementation of IT 


\section{REFERENCES}

Bouldin, B. (1989). Agents of change: Managing the introduction of automated tools. Yourdon Press, Englewood Cliffs, NJ.

Eason, K. (1988). Information technology and organizational change. Taylor and Francis, London.

Downs, G.W., and Mohr, L.B. (1976). Conceptual issues in the study of innovation. Administrative Science Quarterly 21, 700-714.

Fichman, R.G. Information technology diffusion: A review of empirical research. In Proceedings of the 13th International Conference on Information Systems, Dec 13-16, 1992.

Fowler, P. and Rifkin, S. (1990). The Software Engineering Process Group Guide. Technical Report CMU/SEI-90-TR-24; ADA235784. The Software Engineering Institute, Pittsburgh, PA.

Fowler, P. and Levine, L. (1992). Toward a problem solving approach to software technology transition. In J. Van Leeuwen (Ed.), Proceedings of the IFIP 12th World Computer Congress, vol. 1, 57-64. Madrid, Spain. North Holland, Elsevier Science Publishers, The Netherlands.

Fowler, P. and Levine, L. (1994). From theory to practice: Technology transition at the Software Engineering Institute. In Proceedings of the Hawaii International Conference on System Sciences, Maui, HI. IEEE Computer Society Press.

Kwon, T.H. and Zmud, R.W. (1987). Unifying the fragmented models of information systems implementation. In Boland, R.J. Jr., and Hirschheim, R.A. (Eds). Critical issues in information systems research. John Wiley and Sons, Chichester.

Leonard-Barton, D. (1987). Implementing structured software methodologies: A case of innovation in process technology. Interfaces 17, 3 (May-June 1987), 6-17.

Levine, L., (Ed.). (1994). Proceedings of the First International Federation for Information Processing (IFIP) Technical Committee 8 Working Conference on Diffusion, Transfer and Implementation of Information Technology, Champion, PA. North Holland, Elsevier Science Publishers, The Netherlands.

Lien, L. (1992) Pricing and packaging technology for international transfer. In McGovern, J. et al. (eds.), Internationalizing Technology Transfer: Proceedings of the Technology Transfer Society 17th Annual Meeting and International Symposium, June 24-26, 1992, Atlanta, Georgia.

McKenney, J. (1995) Waves of change: business evolution through information technology. Harvard Business School Press, Boston, MA.

Moore, G. (1991) Crossing the chasm: Marketing and selling technology products to mainstream customers. Harper Business.

Morton, R. (Ed.), (1983). Proceedings of the IEEE Computer Society Workshop on Software Engineering Technology Transfer. Miami Beach, FL. IEEE Computer Society Press.

Nord, W.R. and Tucker, S. (1987). Implementing routine and radical innovations. D.C. Heath, Lexington, MA.

Pressman, R. (1988). Making software engineering happen: A guide for instituting the technology. Prentice-Hall, Englewood Cliffs, NJ. 
Przybylinski, S. and Fowler, P. (Eds.). (1987) Transferring Software Engineering Tool Technology, Santa Barbara, CA. The IEEE Computer Society Press.

Redwine, S. T. et al. (1984). DoD related software technology requirements, practices, and prospects for the future. (Technical Report IDA Paper P-1788). Institute for Defense Analysis, Alexandria, VA.

Roberts, E. (1991). Entrepreneurs in high technology: Lessons from MIT and beyond. Oxford University Press, New York.

Rogers, E. M. (1983). Diffusion of innovations. Free Press, New York.

Strauss, S. and Ebenau, R.G. (1994). Software Inspections Process. McGraw-Hill, Inc., New York

Von Hippel, E. (1988).The sources of innovation. Oxford University Press, New York.

Tornatzky, L. G. and Fleischer, M. (1990). The processes of technological innovation. Lexington Books, Lexington, MA.

Zmud, R.W. and Apple, L.E. (1992). Measuring technology incorporation/infusion. Journal of Product Innovation Management 9, 148-155. 